\title{
Öğretmenlerin Yaşam Boyu Öğrenme Eğilimleri ile İş Doyumları Arasındaki İlişkinin İncelenmesi
}

DOI: 10.26466/opus.696882

\author{
* \\ Şeyda Sevinç - Mustafa Çelebi ** \\ * Ölçme ve Değerlendirme Uzm., Kayseri \\ E-Posta: seydakelesoglu@gmail.com \\ ORCID: $0000-0003-4715-4827$ \\ ** Prof. Dr. Erciyes Üniversitesi, Eğitim Fakültesi \\ E-Posta: mdcelebi@gmail.com \\ ORCID: $\underline{0000-0002-0325-7528}$
}

\begin{abstract}
Öz
Yaşam boyu öğrenme, insanların yaşama ilişkin bilgi ve becerilerini geliştirmek amactyla gerçekleştirilen tüm etkinlikleri içeren bir kavram olarak tanımlanabilir. Yaşam boyu öğrenme yaklaşımına göre eğitici; öğrencilerin ya da öğrenenlerin kendi amaçlarını belirlemeleri ve bu amaca ulaşırken izleyecekleri yolları belirlemeleri konusunda kılavuz olmalıdır. Eğitim kurumlarında öğretmenlerin ya da çalışanların duygusu, coşkusu, heyecanı büyük önem taşımaktadır. Öğretmenlerin iş verimini etkileyen, kaliteli iş yapmaların sağlayan önemli değişkenlerden biri şüphesiz $k i$ iş doyumudur. İş doyumu, kişilerin işini ya da işi ile ilgili süreci değerlendirmesi sonucunda ulaştığı memnuniyetlik durumu olarak tanımlamaktadır. Bireylerin iş doyumları üzerinde etkili olan pek çok özellik vardır. Bunlar işin yapıldığı fiziksel ortam, psikolojik değiş̧kenler ve demografik özelliklerdir. Alanyazın incelendiğinde öğretmenlerin iş doyumlarına ve yaşam boyu öğrenme eğilimlerinde etkili olan değişkenlerin sıklıkla incelendiği ancak ikisinin bir arada ilişkilerinin incelendiği az sayıda çalışmaya rastlanmıştır. Yapılan çalışmada bu iki değiş̧ken arasındaki ilişkilerin belirlenmesi hedeflenmiştir. Kayseri'de görev yapan toplam 250 öğretmen ile araştırma yürütülmüştür. Yapılan çalışmada öğretmenlerin yaşam boyu öğrenme eğilimleri ve iş doyumları arasında anlaml düzeyde ancak düşük bir ilişki bulunmuştur.
\end{abstract}

Anahtar Kelimeler: Yaşam boyu ö̆grenme, iş doyumu, eğitim, öğretmen 


\title{
Investigating the Relationship Between Lifelong Learning Trends and Job Satisfaction of Teachers
}

\begin{abstract}
Lifelong learning can be assigned as a concept of all activities performed to improve people's knowledge and skills. Lifelong learning approach; it should be a guide for learners to set their own goals and determine the paths to be taken to achieve this goal. Emotions, enthusiasm and excitement of teachers or employees are of great importance in educational institutions. Undoubtedly, job satisfaction is one of the critical variant that affect teachers' job productivity and enable them to do quality work. Job satisfaction is defined as the level of satisfaction that people reach as a result of evaluating their work. There are many features that affect individuals' job satisfaction. These are physical environment, psychological variables and demographic characteristics. When the articles was checked out, it was asseted that there were few academic articles that checked out the variables affecting the job satisfaction and lifelong learning tendencies of teachers, but the relations of the two were examined together. The purpose of this articles is to check out the relationship between teachers' lifelong learning dispositions and job satisfaction. Teachers were employed in Kayseri. In the study, a significant but low relationship was found between teachers' lifelong learning tendencies and job satisfaction.
\end{abstract}

Keywords: Lifelong learning, job satisfaction, education, teacher 


\section{Giriş}

Yaşam boyu öğrenme, insanların yaşama ilişkin bilgi ve becerilerini geliştirmek amaciyla, eğitim düzeyine, yaşa, ekonomik duruma vb. bakılmaks1zın okul içi ya da dışında gerçekleştirilen tüm etkinlikleri kapsayan temel bir kavram olarak tanımlanabilir. Avrupa Birliği, yaşam boyu öğrenme kavramını; kişinin yaşamı süresince sahip olduğu bilgilerini, becerilerini ve yeterliklerini bireysel, sosyal ya da meslek hayatında geliştirmeyi hedefleyen bütün etkinliklere katılması şeklinde ifade etmiştir (Avrupa Komisyonu, 2002). Dolayısı ile yaşam boyu öğrenme süreci bireylerin olduğu her yerde örgün veya yaygın öğrenme yoluyla gerçekleşebilmektedir (Dinevski ve Dinevski, 2004). Yaşam boyu öğrenme de eğitim süreci, anaokulundan başlayıp üniversite yıllarına kadar sürdüğü ve bu süreçle sınırlı kalmadığ bilinmektedir. Amaç bireylerin farklı öğrenme teknikleriyle yeteneklerini, bilgilerini ve yeterliliklerini geliştirilmek, yeni bilgi ve becerileri kazanmalarını sağlamaktır (Hayat boyu öğrenme nedir?, 2019). Bu yüzden yaşam boyu öğrenme; bilgi ve yeterliiklerin gelişimini desteleyen tüm eğitim, öğreitm ve öğrenme etkinliklerini içermektedir (Güçlü, 2019a)

Yaşam boyu öğrenme kavramı, 1920'lerde Eduard Lindeman, Basil Yeaxle ve yapılandırmacılık kuramına ışık tutan düşünürlerden John Dewey tarafından gündeme gelmiştir (Koç ve İzci, 2012). Literatür incelendiğinde, yaşam boyu öğrenmenin birçok araştırmacı tarafından farklı şekillerde tanımlandığı görülmüştür. OECD, bireyin hayatı boyunca devam eden, onun gelişiminde ve değişiminde önemli bir işlevi olan sonsuz bir etkinlik olarak tanımlamıştır (Ersoy ve Yılmaz, 2009). Jarvis (2004), kişisel ve kurum ile öğrenmenin bir bütünü olarak tanımlarken, Holmes (2002) düzen ve bakış açısı şeklinde ifade etmiştir. Yaşam boyu öğrenme 21. yüzyılın son çeyreğinde dünyada, 2000'li ylllarda ise Türkiye'nin gündemine girmiştir. Türk eğitim sisteminde bu yaklaşıma çok önem verilmiş ve "Hayat Boyu Öğrenme" adında MEB'e bağlı olarak çalışmalar yürüten bir genel müdürlük kurulmuştur (Güleç, Çekiç ve Demirhan, 2013).

Yaşadığımız bilgi çağında bireyin bilgiyi kullanmayı, yorumlamayı, değiştirmeyi ve yeni bilgiler oluşturmayı bilmesi gerekmektedir. Bilgi çağında bilgi çok çabuk yenilendiği için, bireyler öğrenmeyi nasıl öğreneceğini bilmeli ve öğrenmeyi öğrenmeye odaklanmalıdır (Ekiz, 2006; Köymen, 2015). Şüphesiz ki burada en büyük görev okullara; bireylere rol model olacak 
olan öğretmenlere düşmektedir. Yaşam boyu öğrenme yaklaşımına göre eğitici; öğrencilerin ya da öğrenenlerin kendi amaçlarını belirlemeleri ve bu amaca ulaşırken izleyecekleri yolları belirlemeleri konusunda kılavuz olmalıdır (Jarman, Mcaleese ve Mcconnell, 1997; Steward, 2009). Öğrenci de en yakınında olan öğretmenini gözlemleyerek bilgiyi kullanmayı, yorumlamayı, yeni bilgiler oluşturmayı dolayısı ile çağın gerisinde kalmamayı öğrenecektir. Bu yüzden de günümüz öğretmenlerinin bu becerilere sahip olması ve bu becerileri aktif bir şekilde sınıfında ve yaşamında kullanması gerekmektedir.

Yaşam boyu öğrenmeye ilişkin alanyazın tarandığında öncelikle kavramın ne olduğuna ve nasıl geliştirilebileceğine ilişkin çalışmalara (Atik-Kara ve Kürüm, 2007; Diker Coşkun, 2009; Kirby ve vd., 2010; Şahin ve diğerleri, 2010; Evin Gencel, 2013; Hunde ve Tacconi, 2014; Goodrich, 2015; Tunca, Alkın-Şahin ve Aydın, 2015; Yıldırım, 2015; Kazu ve Erten, 2016; Pınarcık ve vd., 2016; Güçlü, 2019b) sıklıkla rastlanmıştır. Bu çalışmalarda ayrıca kavramı çeşitli değişkenlere göre (branş, mesleki kıdem, cinsiyet, mezuniyet durumu vb) inceleyen çok sayıda çalışma (Akkoyunlu ve Kurbanoğlu, 2004; Demirel ve Akkoyunlu, 2010; Yaman ve Yazar, 2015; Gencel, 2013; Özçiftçi ve Çakır, 2015) olduğu ve bu değişkenlerin incelendiği çalışmaların bazılarında anlamlı olarak farklılaşmaların olduğu görülmüştür. Bu farklılıkları ortadan kaldırabilmek için bireylere hizmet içi ve hizmet dışı eğitim kursları, seminer, atölye çalışmaları vb eğitim çalışmalarının düzenlenmesi gerektiği belirtilmektedir. Son yıllarda ise bilgi okuryazarlı̆̆ı öz-yeterlikleri (Demirel ve Akkoyunlu, 2010; Özgür, 2016), mesleki yeterlik algıları (Kösterelioğlu ve Ayra, 2015), akademik başarı (Akkuş, 2008; Diker Coşkun, 2009), okuduğunu anlama becerileri (Akkuş, 2008) ve iş doyumu (Kağan ve Yılmaz, 2018) ile ilişkilerinin incelendiği çalışmalar görülmüştür.

Hızlı bir dönüşümün görüldüğü günümüz dünyasında eğitim, sosyal değişmenin önemli güçlerinden birisi olarak değerlendirilmektedir (Güçlü ve Bozgeyikli, 2017). Eğitim kurumlarında ise istenilen kalite, bireylerle gerçekleştirilmektedir. Verilen eğitimin kalitesinin ortaya çıkmasında öğretmenlerin ya da çalışanların isteklilikleri büyük önem taşımaktadır (Alıç, 1996). Öğretmenlerin yaptıkları işin kalitesini ve yapılan işin verimini artırmalarına katkı sağlayan önemli değişkenlerden biri şüphesiz ki iş doyumudur (Kağan ve Yılmaz, 2018). İlk iş doyumu araştırmaları Birinci Dünya Savaşı yıllarında F.Taylor tarafından başlatılmıştır. Taylor'a göre az yorucu 
ve yüksek ücretli işler, işgörenin verimini artırmaktadır (Çarıkçı ve Oksay, 2004) Locke (1976), bireyin işini ya da işi ile ilgili süreci değerlendirmesi sonucunda ulaştı̆̆ı memnuniyeti iş doyumu olarak tanımlamaktadır.

İş doyumu kavramına ilişkin alanyazın tarandığında; çevresel, psikolojik ve demografik özelliklere göre öğretmenlerin iş doyumlarını belirleyen ve çeşitli değişkenlerle ilişkilerini inceleyen birçok araştırmanın yapıldığı (Dinham ve Scott, 1996; Avşaroğlu, Deniz ve Kahraman, 2005; Zembylas ve Papanastasiou, 2005; Demirel, 2006; Gençay, 2007; Taşdan ve Tiryaki, 2008; Erdem ve Demirel, 2009; Şahin ve Dursun, 2009; Günbayı ve Toprak, 2010; Menon ve Reppa, 2011; Kış, Gürgür ve Akçamete, 2012; Yılmaz ve Altınkurt, 2012) görülmüştür. Ayrıca öğretmenlerin iş doyumlarının yaş, kıdem, medeni durum gibi çeşitli değişkenler açısından incelendiği ve anlamlı farklılaşmaların olmadığı çalışmalara (Kağan, 2005; Sulu, 2007; Gürbüz, 2008; Öztürk ve Deniz, 2008; Girgin, 2009; Özyürek, 2009; Y1lmaz ve Izgar, 2009) rastlanmış ancak bu değişkenlere göre anlamlı farklılaşmaların olduğunu gösteren çalışmaların da (Marx ve Granger, 1992; Çelik, 2003; Kağan, 2005; Dilsiz, 2006) olduğu görülmüştür.

Doyum, kişisel ve duygusal birçok değişkenden etkilenen, sosyal nitelikli soyut bir kavram olup sadece kişinin hissederek tanımladığı, onun iç dünyasını anlatan karmaşık bir kavramdır (Şencan, 2011). Bu yüzden de bireylerin iş doyumları üzerinde etkili olan pek çok özellik vardır. Bunlar çevresel (yapılan iş ve çevresi), ruhsal (şahsiyet, tavır, muamele) ve demografik (yaş, cinsiyet) özelliklerdir (Crossman ve Haris, 2006). Yapılan araştırmalar, çalışanların iş doyumunun yüksek olmasının; bireylerin moralini, özgüvenini, performansını artırdığını; hastalıkları, stresi, endişeleri, şikayetleri ve işten ayrılma sayılarını azalttı̆̆ını göstermektedir (Gedik vd., 2009)

\section{Araştırmanın Amacı}

Alanyazın incelendiğinde; öğretmenlerin iş doyumlarına ve yaşam boyu öğrenme eğilimlerine etki eden değişkenlerin sıklıkla incelendiği ancak ikisinin bir arada ilişkilerinin incelendiği az sayıda çalışmaya rastlanmıştır. $\mathrm{Bu}$ iki kavramın bir arada incelenmesinin araştırmalara katkı getireceği düşünülmektedir. 


\section{Araştırma Problemi}

Çalışmada, öğretmenlerin yaşam boyu öğrenme eğilimleri ile iş doyumları arasındaki ilişki incelenmeye çalışılmıştır. Çalışma sonucunda edinilen bulgulara göre öğretmenlerin yaşam boyu öğrenme eğilimleri üzerinde etkisi olduğu düşünülen bir yapının daha ortaya çıarılması hedeflenmektedir.

\section{Araştırmanın alt problemleri}

1. Öğretmenlerin yaşam boyu öğrenme eğilimleri nasıldır? Cinsiyetlerine, branşlarına, deneyimlerine, mezuniyetlerine göre anlamlı olarak farkl1laşmakta mıdır?

2. Öğretmenlerin iş doyumları ne düzeydedir? Cinsiyetlerine, branşlarına, deneyimlerine, mezuniyetlerine göre anlamlı olarak farklılaşmakta mıdır?

3. Öğretmenlerin yaşam boyu öğrenme eğilimleri ile iş doyumları arasındaki ilişki nasıldır?

\section{Yöntem}

\section{Araştırmanın Modeli}

Öğretmenlerin yaşam boyu öğrenme eğilimleri ile iş doyumları arasındaki ilişkilerinin incelendiği çalışma, var olan durumu olduğu şekliyle betimlediği için tarama modeli, iki ya da ikiden fazla sayıdaki değişkenler arasındaki ilişkinin derecesini belirlemeyi amaçladığı için de ilişkisel tarama modelidir. Karasar'a göre (2013) ilişkisel tarama modeli, değişkenlerin birbirleri ile birlikte gösterdiği değişimin varlığını belirlemeyi ya da derecesini ortaya çıkarmayı hedeflemektedir.

\section{Çalışma Grubu}

Bu çalışmanın evreni, 2018-2019 eğitim-öğretim yılında Kayseri ilinde ilkokul ve ortaokullarda görev yapan öğretmenlerden oluşmaktadır. Çalışmada evren geniş olması nedeniyle örnekleme yoluna gidilmiş, araştırmanın çalışma grubu oluşturulurken, amaçlı örnekleme türlerinden kolay ulaşılabilir durum örneklemesi yapılmıştır. Bu örneklemede araştırmacı rahat erişebileceği bir örneklem ile çalışmasını yürütür. Bu yöntem yaygın olarak kulla- 
nılmakta, araştırmaya hız ve pratiklik kazandırmakta ancak sonuçları daha az genellenebilmektedir (Yıldırım ve Şimşek, 2008). Yapılan araştırma Kayseri'de görev yapan toplam 250 öğretmen ile yürütülmüştür.

Araştırmaya katılan öğretmenlerin demografik dağılımlarını gösteren bilgiler Şekil 1'de verilmiştir.
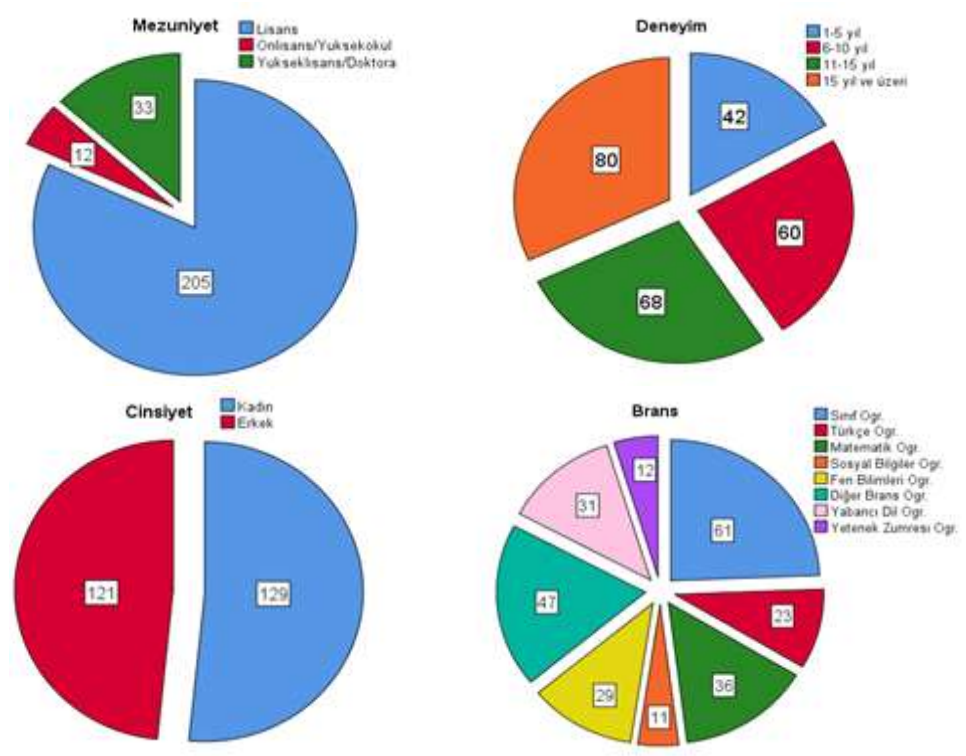

Şekil 1.Araştırmaya katılan öğretmenlerin demografik özellikleri

Örneklem dağılımı incelendiğinde branşlara göre araştırmaya en çok s1nıf öğretmeninin, en az da sosyal bilgiler ve yetenek zümresi öğretmenlerinin katıldığı görülmektedir. Cinsiyet açısından ise kadın ve erkek öğretmenlerinin sayılarının birbirine yakın olduğu, öğretmenlerin büyük çoğunluğunun lisans mezunu olduğu görülmektedir. Ayrıca araştırmaya katılan öğretmenlerin büyük çoğunluğu 15 yll ve üzeri deneyime sahiptir.

\section{Veri Toplama Araçları}

Yapılan araştırmada "Kişisel Bilgi Formu", "Yaşam Boyu Öğrenme Eğilimleri Ölçeği" ve "İş Doyumu Ölçeği" uygulanmıştır. Kişisel bilgi formunda katılımcılara araştırmanın bağımsız değişkenlerine ilişkin bilgiler sorulmuştur. 


\section{Yaşam boyu öğrenme eğilimleri ölçeği (YBO)}

Araştırmada, Diker Coşkun'un (2009) öğretmenler için geliştirdiği Yaşam Boyu Öğrenme Eğilimleri Ölçeği kullanılmıştır. Ölçek, 27 maddeden oluşmakta ve "Çok uyuyor- hiç uymuyor" şeklinde 6'lı likert tipindedir. Ölçeğin güvenirlik katsayısı 0.89 bulunmuştur. Ölçek dört alt boyuttadır. Bunlardan Motivasyon (1-6. maddeler), Sebat (7-12. maddeler) alt boyutu olumlu maddelerden oluşmakta iken Öğrenmeyi Düzenlemede Yoksunluk (13-18. maddeler) ve Merak Yoksunluğu (19-27. maddeler) alt boyutu olumsuz maddelerden oluşmakta olup ters kodlanması gerekmektedir. Ölçekten alınabilecek maksimum ve minimum puanlar Tablo 1'de verilmiştir.

\begin{tabular}{lll} 
Tablo 1.Yaşam boyu öğrenme e ğ ilimleri ölçeği puanlan & \\
\hline Yaşam boyu öğrenme alt boyutları & Min & Mak \\
\hline Motivasyon & 6 & 36 \\
Sebat & 6 & 36 \\
Ö̆ğrenmeyi Düzenlemede Yoksunluk & 6 & 36 \\
Merak Yoksunluğu & 9 & 54 \\
Ölçeğin tamamı & 27 & 162 \\
\hline
\end{tabular}

Bu çalışmada ölçeğin tamamına ilişkin yapılan güvenirlik analizinde Cronbach Alpha katsayısı 0.62 bulunmuştur.

\section{İş doyumu ölçeği (ID)}

Araştırmada, Hackman ve Oldham'ın (1975) geliştirdiği ve Silah (2002) tarafından da Türkçeye uyarlanan ölçek öğretmenlerin iş doyumlarını belirlemek amacıyla kullanılmıştır. İş Doyum Ölçeği 14 maddeden oluşmakta ve beşli likert tipindedir. Ölçek tek boyutludur. Ölçekten alınabilecek enaz puan (14x1) 14 ve en çok puan (14x5) 70 olarak belirlenmiştir. Ölçeğin güvenirlik katsayısı 0.95 olarak bulunmuştur.

Bu çalışmada ölçeğin tamamı için yapılan güvenirlik analizinde Cronbach Alpha iç tutarlık katsayısı 0.77 bulunmuştur.

\section{Verilerin Toplanması ve Analizi}

Uygulama 2018-2019 yılının ikinci eğitim-öğretim döneminde araştırmacılar tarafından yapılmıştır. Veriler düzenlendikten sonra SPSS programında analize uygun hale getirilmiştir. Alt problemlere cevap verilmeden dağılım özellikleri ortaya koyulmuş ve betimsel istatistikler (ortalama, standart 
sapma, çarpıklık, basıklık) hesaplanmıştır. İncelenen istatistikler sonucunda ölçeklere ilişkin verilerin normal dağılmadığı $(p<.05)$ tespit edilmiştir. Verilerin analizleri yapılırken nonparametrik yöntemlerden "Mann Whitney U", "Kruskal Wallis" ve "Spearman Korelasyon Katsayısı" kullanılmıştır. Verilerin analizlerinde anlamlılık düzeyi 0.05 olarak alınmıştır.

Korelasyon katsayısının büyüklük bakımından yorumlanmasında Büyüköztürk'ün (2004) korelasyon ilişkisini yorumlamada belirlediği "0.70$1.00 \rightarrow$ Yüksek İlişki”, “0.70-0.30 $\rightarrow$ Orta İlişki”, “0.30-0.00 $\rightarrow$ Düşük İlişki” aralıkları temel alınmıştır.

Yaşam Boyu Öğrenme Eğilimleri Ölçeğinde verilen cevaplar 1 ile 6 puan aralığında değişmektedir. Dereceleme maddeleri "6: Çok uyuyor" ve "1: Hiç uymuyor" seçeneklerinden oluşmaktadır. Yaşam boyu öğrenme eğilimleri ölçeği aralıkları Tablo 2'de verilmiştir.

Tablo 2. Yaşam boyu öğrenme eğilimleri ölçeği aralıklan

\begin{tabular}{ll}
\hline Yaşam boyu öğrenme eğilimleri düzeyi & Puan aralığı \\
\hline Azdır. & $27,0-49,5$ \\
Kısmen azdır. & $49,6-72,0$ \\
Çok azdır. & $72,1-94,5$ \\
Kısmen vardır. & $94,6-117,0$ \\
Vardır. & $117,1-139,5$ \\
Yüksektir. & $139,6-162,0$ \\
\hline
\end{tabular}

İş Doyumu Ölçeğinde verilen cevaplar 1 ile 5 puan aralığında değişmektedir. Dereceleme maddeleri "1-Beni hiç tatmin etmez" ve "5-Beni çok tatmin eder" şeklindedir. Ölçeğin değerlendirilmesinde kullanılan puan aralıkları Tablo 3'de verilmiştir.

Tablo 3. İş doyumu ölçeği aralıkları

\begin{tabular}{ll}
\hline İs Doyumu Düzeyi & Puan aralı̆̆ı \\
\hline Çok düşük düzeydedir. & $14-24$ \\
Düşük düzeydedir. & $25-35$ \\
Orta düzeydedir. & $36-48$ \\
Yüksek düzeydedir. & $49-59$ \\
Çok yüksek düzeydedir. & $60-70$ \\
\hline
\end{tabular}

\section{Bulgular}

Araştırmanın bu bölümünde bulgular, ilgili araştırma soruları doğrultusunda sirasiyla verilmektedir. 


\section{Öğretmenlerin Yaşam Boyu Öğrenme Eğilimlerine Yönelik Bulgular}

Araştırmada yanıtı aranan ilk soru, öğretmenlerin yaşam boyu öğrenme eğilimlerinin ne düzeyde olduğu ve cinsiyet, branş, deneyim ve mezuniyetlerine göre anlamlı olarak farklılaşıp farklılaşmadığının belirlenmesidir. Yöntem bölümünde belirtilen sinılara göre elde edilen verilerin aritmetik ortalamaları yorumlanmıştır. Araştırmanın bu alt probleminin yanıtlanmasında ölçeğin tamamına verilen cevaplara göre elde edilen puanlar dikkate alınmıştır. Sözü edilen puanlara ilişkin ortalamalar Tablo 4' de sunulmuştur.

Tablo 4. Öğretmenlerin yaşam boyu öğrenme eğilimlerine yönelik bulgular

\begin{tabular}{llllll}
\hline Değisskenler & n & Min & Mak & M & $\begin{array}{l}\text { Çeyrek } \\
\text { sapma }\end{array}$ \\
\hline Yaşam Boyu Öğrenme Eğilimleri & 250 & 64 & 162 & 133 & 20,89 \\
Motivasyon & 250 & 19 & 36 & 34 & 3,32 \\
Sebat & 250 & 6 & 36 & 31 & 4,69 \\
Öğrenmeyi Düzenlemede Yoksunluk & 250 & 11 & 36 & 28 & 6,32 \\
Merak Yoksunluğu & 250 & 9 & 54 & 45 & 12,53 \\
\hline
\end{tabular}

Ölçekten alınan puanlara bakıldığında; minimum puanın 64, maksimum puanın 162, ölçek ortalamasının ise (Mean (M)) 133 olduğu ve bu puanın da ölçek orta puanının $(94,5)$ üzerinde olduğu görülmektedir. Buna göre öğretmenlerin yaşam boyu öğrenmelerinin yeterli düzeyde olduğu söylenebilir. Alt boyutlara ilişkin istatistikler incelendiğinde ise motivasyon $(M=34)$, sebat $(M=31)$, öğrenmeyi düzenlemede yoksunluk $(M=28)$ ve merak yoksunluğu $(\mathrm{M}=45)$ olduğu ve bu puanlarında ölçek orta puanlarının üstünde olduğu görülmektedir. Bu sebeple de öğretmenlerin çoğunlukla yaşam boyu öğrenme eğilimini benimsedikleri, yeni bilgi ve becerileri öğrenmeye karşı istekli oldukları ve bunu yaşam felsefesi yaptıkları söylenebilir. Ayrıca kendileri için zorunlu olmayan öğrenme ortamlarında bile karşılarına çıkan sorunlar karşısında yılmadıkları, öğrenmek için uğraştıkları anlaşlmaktadır.

\section{Öğretmenlerin Yaşam Boyu Öğrenme Eğilimlerinin Cinsiyet Değişkenine Yönelik Bulgular}

Öğretmenlerin yaşam boyu öğrenme eğilimlerinin cinsiyet değişkenine göre manidar şekilde farklılık gösterip göstermediğini belirlemek için yapılan Mann Whitney U analizine ilişkin bulgular Tablo 5'de sunulmuştur. 
Tablo 5. Öğretmenlerin yaşam boyu öğrenme eğilimleri test puanlarnnn cinsiyete göre sonuçları

\begin{tabular}{|c|c|c|c|c|c|c|c|}
\hline Değişkenler & Cinsiyet & $\mathbf{n}$ & S.O & S.T & $\mathbf{U}$ & $\mathbf{z}$ & p \\
\hline \multirow{2}{*}{$\begin{array}{ll}\text { Yaşam } & \text { Boyu } \\
\text { Öğrenme } & \\
\text { Eğgilimleri } & \end{array}$} & Kadın & 129 & 134,92 & 17404,50 & \multirow[b]{2}{*}{6589,500} & \multirow[b]{2}{*}{$-2,127$} & \multirow[b]{2}{*}{, $033^{*}$} \\
\hline & Erkek & 121 & 115,46 & 13970,50 & & & \\
\hline \multirow{2}{*}{ Motivasyon } & Kadın & 129 & 126,10 & 16266,50 & \multirow{2}{*}{7727,500} & \multirow{2}{*}{,- 136} & \multirow{2}{*}{,891 } \\
\hline & Erkek & 121 & 124,86 & 15108,50 & & & \\
\hline \multirow{2}{*}{ Sebat } & Kadın & 129 & 124,98 & 16123,00 & \multirow{2}{*}{7738,000} & \multirow{2}{*}{,- 117} & \multirow{2}{*}{,907 } \\
\hline & Erkek & 121 & 126,05 & 15252,00 & & & \\
\hline \multirow{2}{*}{$\begin{array}{l}\text { Öğrenmeyi } \\
\text { Düzenlemede } \\
\text { Yoksunluk }\end{array}$} & Kadın & 129 & 136,23 & 17574,00 & \multirow[b]{2}{*}{6420,000} & \multirow[b]{2}{*}{$-2,447$} & \multirow[b]{2}{*}{, $014^{*}$} \\
\hline & Erkek & 121 & 114,06 & 13801,00 & & & \\
\hline \multirow{2}{*}{$\begin{array}{l}\text { Merak } \\
\text { Yoksunluğu }\end{array}$} & Kadın & 129 & 133,14 & 17175,50 & \multirow{2}{*}{6818,500} & \multirow{2}{*}{$-1,728$} & \multirow{2}{*}{,084 } \\
\hline & Erkek & 121 & 117,35 & 14199,50 & & & \\
\hline
\end{tabular}

${ }^{*} \mathrm{p}<0,05$

Tablo 5 incelendiğinde Ölçeği, 121 Erkek, 129 Kadın öğretmenin cevapladığı, erkek öğretmenlerin ölçekten aldıkları toplam puanların ortalamasının 115,46, kadın öğretmenlerin ise 134,92 bulunmuştur. Öğretmenlerin ölçeğin tamamından ve Öğrenmeyi Düzenlemede Yoksunluk alt ölçeğinden aldıkları puanlarda cinsiyete göre kadın öğretmenler lehine anlamlı farklılık $(p<.05)$ olduğu görülmüştür. Diğer alt boyutlardan alınan puanlarda öğretmenlerin cinsiyetlerine göre manidar bir farklılık olmadığ 1 (p>.05) görülmüştür.

\section{Öğretmenlerin Yaşam Boyu Öğrenme Eğilimlerinin Branş Değişkenine Yö- nelik Bulgular}

Yaşam Boyu Öğrenme Eğilimleri Ölçeği puanlarının öğretmenlerin branşlarına göre farklılaşıp farklılaşmama durumunu ortaya koymak amaciyla Kruskal Wallis testi yapılmış, bulgular Tablo 6' da verilmiştir. 
Tablo 6. Branşa göre yaşam boyu öğrenme eğilimleri ölçeği puanlarna ilişkin sonuçlar

\begin{tabular}{|c|c|c|c|c|c|}
\hline Değişkenler & Branş & $\mathbf{n}$ & $\begin{array}{l}\text { Gruplar Arası } \\
\text { Fark }\end{array}$ & $\begin{array}{l}\text { Kruskal } \\
\text { Wallis }\end{array}$ & $\mathbf{p}$ \\
\hline \multirow{8}{*}{$\begin{array}{l}\text { Yaşam Boyu } \\
\text { Öğrenme } \\
\text { Eğilimleri }\end{array}$} & Sınıf Öğretmenliği & 61 & 135,65 & \multirow[t]{8}{*}{10,695} & \multirow[t]{8}{*}{ 153 } \\
\hline & Türkçe Öğretmenliği & 23 & 109,17 & & \\
\hline & Matematik Öğretmenliği & 36 & 103,71 & & \\
\hline & Sosyal Bilgiler Ö̈̆gretmenliği & 11 & 103,95 & & \\
\hline & Fen Bilimleri Öğretmenliği & 29 & 122,29 & & \\
\hline & Diğer Branş Öğretmenliği & 47 & 123,90 & & \\
\hline & Yabancı Dil Öğretmenliği & 31 & 146,79 & & \\
\hline & Yetenek Zümresi Öğretmenliği & 12 & 149,33 & & \\
\hline \multirow{8}{*}{ Motivasyon } & Sınıf Öğretmenliği & 61 & 125,81 & \multirow[t]{8}{*}{7,117} & \multirow[t]{8}{*}{,417 } \\
\hline & Türkçe Öğretmenliği & 23 & 122,39 & & \\
\hline & Matematik Öğretmenliği & 36 & 106,01 & & \\
\hline & Sosyal Bilgiler Öğretmenliği & 11 & 145,09 & & \\
\hline & Fen Bilimleri Öğretmenliği & 29 & 112,50 & & \\
\hline & Diğer Branş Öğretmenliği & 47 & 131,41 & & \\
\hline & Yabancı Dil Öğretmenliği & 31 & 135,90 & & \\
\hline & Yetenek Zümresi Öğretmenliği & 12 & 151,75 & & \\
\hline \multirow{8}{*}{ Sebat } & Sınıf Öğretmenliği & 61 & 123,52 & \multirow[t]{8}{*}{6,572} & \multirow[t]{8}{*}{,475 } \\
\hline & Türkçe Öğretmenliği & 23 & 117,78 & & \\
\hline & Matematik Öğretmenliği & 36 & 110,81 & & \\
\hline & Sosyal Bilgiler Öğgretmenliği & 11 & 135,82 & & \\
\hline & Fen Bilimleri Öğretmenliği & 29 & 136,19 & & \\
\hline & Diğer Branş Öğretmenliği & 47 & 122,04 & & \\
\hline & Yabancı Dil Öğretmenliği & 31 & 128,26 & & \\
\hline & Yetenek Zümresi Öğretmenliği & 12 & 165,58 & & \\
\hline \multirow{8}{*}{$\begin{array}{l}\text { Öğrenmeyi } \\
\text { Düzenlemede } \\
\text { Yoksunluk }\end{array}$} & Sınıf Öğretmenliği & 61 & 129,11 & \multirow[t]{8}{*}{9,315} & \multirow[t]{8}{*}{,231 } \\
\hline & Türkçe Öğretmenliği & 23 & 104,57 & & \\
\hline & Matematik Öğretmenliği & 36 & 118,97 & & \\
\hline & Sosyal Bilgiler Öğgretmenliği & 11 & 103,68 & & \\
\hline & Fen Bilimleri Öğretmenliği & 29 & 113,91 & & \\
\hline & Diğer Branş Öğretmenliği & 47 & 125,87 & & \\
\hline & Yabancı Dil Öğretmenliği & 31 & 151,84 & & \\
\hline & Yetenek Zümresi Öğretmenliği & 12 & 145,33 & & \\
\hline \multirow{8}{*}{$\begin{array}{l}\text { Merak } \\
\text { Yoksunluğu }\end{array}$} & Sınıf Öğretmenliği & 61 & 136,14 & \multirow[t]{8}{*}{5,773} & \multirow[t]{8}{*}{, 567} \\
\hline & Türkçe Öğretmenliği & 23 & 108,93 & & \\
\hline & Matematik Öğretmenliği & 36 & 122,72 & & \\
\hline & Sosyal Bilgiler Öğretmenliği & 11 & 100,82 & & \\
\hline & Fen Bilimleri Öğretmenliği & 29 & 119,91 & & \\
\hline & Diğer Branş Öğretmenliği & 47 & 119,52 & & \\
\hline & Yabancı Dil Öğretmenliği & 31 & 140,05 & & \\
\hline & Yetenek Zümresi Öğretmenliği & 12 & 133,46 & & \\
\hline
\end{tabular}

${ }^{*} \mathrm{p}<0,05$ 
Tablo 6'da, Öğretmenlerin branşlarına göre ölçeğin tamamından ve alt testlerinden aldıkları puanlarının anlamlı $(p>, 05)$ farklılıklar göstermediği görülmüştür.

\section{Öğretmenlerin Yaşam Boyu Öğrenme Eğilimlerinin Deneyim Değişkenine Yönelik Bulgular}

Öğretmenlerin deneyimlerine göre Yaşam Boyu Öğrenme Eğilimleri Ölçeği puanlarının farklılaşıp farklılaşmama durumunu ortaya koymak amaciyla Kruskal Wallis testi yapılmış, bulgular Tablo 7'de verilmiştir.

Tablo 7. Deneyimlere göre yaşam boyu öğrenme eğilimleri ölçeği puanlarna ilişkin sonuçlar

\begin{tabular}{|c|c|c|c|c|c|}
\hline Değişkenler & Deneyim & $\mathbf{n}$ & Gruplar Arası Fark & Kruskal Wallis & $\mathrm{p}$ \\
\hline \multirow{4}{*}{$\begin{array}{l}\text { Yaşam Boyu } \\
\text { Öğrenme Eğilimleri }\end{array}$} & $1-5 Y_{11}$ & 42 & 109,82 & \multirow[t]{4}{*}{2,472} & \multirow[t]{4}{*}{480} \\
\hline & 6-10 y1l & 60 & 127,08 & & \\
\hline & $11-15$ yil & 68 & 127,76 & & \\
\hline & 15 yıl ve üzeri & 80 & 130,63 & & \\
\hline \multirow{4}{*}{ Motivasyon } & $1-5 Y_{11}$ & 42 & 113,14 & \multirow[t]{4}{*}{1,684} & \multirow[t]{4}{*}{640} \\
\hline & 6-10 yil & 60 & 125,28 & & \\
\hline & $11-15 \mathrm{yll}$ & 68 & 130,53 & & \\
\hline & 15 yıl ve üzeri & 80 & 127,88 & & \\
\hline \multirow{4}{*}{ Sebat } & $1-5 Y_{11}$ & 42 & 113,58 & \multirow[t]{4}{*}{1,891} & \multirow[t]{4}{*}{, 595} \\
\hline & 6-10 yıl & 60 & 128,09 & & \\
\hline & $11-15$ yıl & 68 & 123,29 & & \\
\hline & 15 yıl ve üzeri & 80 & 131,69 & & \\
\hline \multirow{4}{*}{$\begin{array}{l}\text { Öğrenmeyi Düzenle- } \\
\text { mede Yoksunluk }\end{array}$} & $1-5 Y_{11}$ & 42 & 116,32 & \multirow[t]{4}{*}{1,626} & \multirow[t]{4}{*}{654} \\
\hline & 6-10 yıl & 60 & 127,39 & & \\
\hline & $11-15$ yil & 68 & 133,04 & & \\
\hline & 15 yıl ve üzeri & 80 & 122,49 & & \\
\hline \multirow{4}{*}{ Merak Yoksunluğu } & $1-5 Y_{1}$ & 42 & 108,92 & \multirow[t]{4}{*}{3,419} & \multirow[t]{4}{*}{,331 } \\
\hline & 6-10 yil & 60 & 133,20 & & \\
\hline & $11-15 \mathrm{yll}$ & 68 & 122,76 & & \\
\hline & 15 yıl ve üzeri & 80 & 130,76 & & \\
\hline
\end{tabular}

${ }^{*} \mathrm{p}<0,05$

Tablo 7 incelendiğince ölçeğin tamamından ve alt boyutlarından alınan puanlarda öğretmenlerin deneyimlerine göre anlamlı bir farklılık ( $>$ >05) olmadığ1 görülmüştür. 
Öğretmenlerin Yaşam Boyu Öğrenme Eğilimlerinin Mezuniyet Değişkenine Yönelik Bulgular

Öğretmenlerin Yaşam Boyu Öğrenme Eğilimleri Ölçeği test puanlarının mezun oldukları okul türlerine göre farklılaşıp farklılaşmama durumunu ortaya koymak amaciyla Kruskal Wallis testi yapılmış, bulgular Tablo 8'de verilmiştir.

Tablo 8. Öğretmenlerin mezun olduklan okullara göre yaşam boyu öğrenme eğilimleri ölçeği puanlarna ilişkin sonuçlar

\begin{tabular}{|c|c|c|c|c|c|}
\hline Değişkenler & Okul Türü & $\mathbf{n}$ & $\begin{array}{l}\text { Gruplar Arası } \\
\text { Fark }\end{array}$ & $\begin{array}{l}\text { Kruskal } \\
\text { Wallis } \\
\end{array}$ & $\mathrm{p}$ \\
\hline \multirow{3}{*}{$\begin{array}{l}\text { Yaşam } \quad \text { Boyu } \\
\text { Öğrenme Eğilimle- } \\
\text { ri }\end{array}$} & Lisans & 205 & 120,00 & \multirow[t]{3}{*}{8,196} & \multirow[t]{3}{*}{, $017^{*}$} \\
\hline & Önlisans/Yüksekokul & 12 & 173,17 & & \\
\hline & Yükseklisans/Doktora & 33 & 142,35 & & \\
\hline \multirow{3}{*}{ Motivasyon } & Lisans & 205 & 118,44 & \multirow[t]{3}{*}{11,813} & \multirow[t]{3}{*}{, $003^{*}$} \\
\hline & Önlisans/Yüksekokul & 12 & 172,33 & & \\
\hline & Yükseklisans/Doktora & 33 & 152,30 & & \\
\hline \multirow{3}{*}{ Sebat } & Lisans & 205 & 118,11 & \multirow[t]{3}{*}{14,415} & \multirow[t]{3}{*}{, $001^{*}$} \\
\hline & Önlisans/Yüksekokul & 12 & 186,50 & & \\
\hline & Yükseklisans/Doktora & 33 & 149,24 & & \\
\hline \multirow{3}{*}{$\begin{array}{l}\text { Öğrenmeyi Düzen- } \\
\text { lemede Yoksunluk }\end{array}$} & Lisans & 205 & 123,65 & \multirow[t]{3}{*}{1,072} & \multirow[t]{3}{*}{,585 } \\
\hline & Önlisans/Yüksekokul & 12 & 143,79 & & \\
\hline & Yükseklisans/Doktora & 33 & 130,36 & & \\
\hline \multirow{3}{*}{ Merak Yoksunluğu } & Lisans & 205 & 122,35 & \multirow[t]{3}{*}{3,546} & \multirow[t]{3}{*}{ 170 } \\
\hline & Önlisans/Yüksekokul & 12 & 160,83 & & \\
\hline & Yükseklisans/Doktora & 33 & 132,20 & & \\
\hline
\end{tabular}

${ }^{*} \mathrm{p}<0,05$

Tablo 8 incelendiğince öğretmenlerin ölçeğin tamamından ve Motivasyon ve Sebat alt testlerinden aldıkları puanlarının okul türlerine göre anlam$l_{1}(\mathrm{p}<, 05)$ farklılıklar gösterdiği görülmüş̧tür. Diğer alt boyutlarda ise mezun oldukları okul türlerine göre anlamlı $(p>, 05)$ farklılıklar göstermediği görülmüştür.

Ölçeğin tamamında, Motivasyon ve Sebat alt testlerinde farklılığın hangi gruptan kaynaklandığını belirlemek için nonparametrik testlerde parametrik testlerdeki gibi özel karşılaştırma testleri bulunmamaktadır. Bu yüzden de Mann Whitney U testi uygulanarak ikili karşılaştırmalar yapılmış, bulgular Tablo 9'da verilmiştir. 
Tablo 9. Öğretmenlerin mezuniyetlerine göre mann whitney u testi sonuçları

\begin{tabular}{|c|c|c|c|c|c|c|}
\hline Değişkenler & Okul Türü & $\mathbf{n}$ & Sira Ort. & $\mathrm{z}$ & $\mathbf{U}$ & $\mathrm{p}$ \\
\hline \multirow{2}{*}{$\begin{array}{l}\text { Yaşam Boyu } \\
\text { Öğrenme } \\
\text { Eğilimleri Ölçeği }\end{array}$} & Lisans & 205 & 106,50 & \multirow[t]{2}{*}{$-2,425$} & \multirow[t]{2}{*}{717,500} & \multirow[t]{2}{*}{,015 } \\
\hline & Önlisans/Yüksekokul & 12 & 151,71 & & & \\
\hline \multirow{4}{*}{ Motivasyon } & Lisans & 205 & 106,40 & \multirow[t]{2}{*}{$-2,546$} & \multirow[t]{2}{*}{697,500} & \multirow[t]{2}{*}{011} \\
\hline & Önlisans/Yüksekokul & 12 & 153,38 & & & \\
\hline & Lisans & 205 & 115,04 & \multirow[t]{2}{*}{$-2,519$} & \multirow[t]{2}{*}{2468,500} & \multirow[t]{2}{*}{,012 } \\
\hline & Yükseklisans/Doktora & 33 & 147,20 & & & \\
\hline \multirow{4}{*}{ Sebat } & Lisans & 205 & 105,75 & \multirow[t]{2}{*}{$-3,164$} & \multirow[t]{2}{*}{564,500} & \multirow[t]{2}{*}{002} \\
\hline & Önlisans/Yüksekokul & 12 & 164,46 & & & \\
\hline & Lisans & 205 & 115,35 & \multirow[t]{2}{*}{$-2,329$} & \multirow[t]{2}{*}{2532,500} & \multirow[t]{2}{*}{,020 } \\
\hline & Yükseklisans/Doktora & 33 & 145,26 & & & \\
\hline
\end{tabular}

${ }^{*} \mathrm{p}<0,05$

Tablo 9'a göre ölçeğin tamamı, Motivasyon ve Sebat alt testinde Lisans mezunu öğretmenlerin aldıkları puan ortalamalarının Önlisans/Yüksekokul mezunu ögrretmenlerden manidar bir şekilde düşük olduğu görülmüştür. Ayrıca Motivasyon ve Sebat alt testlerinden Lisans mezunu öğretmenlerin aldıkları puan ortalamalarının Yükseklisans/Doktora mezunu öğretmenlerden manidar bir şekilde düşük olduğu görülmüştür.

\section{Öğretmenlerin İş Doyumlarnna Yönelik Bulgular}

Araştırmada yanıtı aranan ikinci soru, öğretmenlerin iş doyumlarının ne düzeyde olduğu ve cinsiyet, branş, deneyim ve mezuniyetlerine göre anlamlı olarak farklılaşıp farklılaşmadığının belirlenmesidir. Elde edilen veriler yorumlanurken, yöntem bölümünde belirtilen aralıklardan faydalanılmıştır. Araştırmanın bu alt probleminin yanıtlanmasında İş Doyumu Ölçeği'nden toplam puanlar alınarak araştırma sorusu yanıtlanmıştır. Sözü edilen puanlara ilişkin ortalama Tablo 10' da sunulmuştur.

Tablo 10. Öğretmenlerin iş doyumlarna yönelik bulgular

\begin{tabular}{llllll}
\hline Değişken & $\mathbf{n}$ & Min & Mak & M & Çeyrek sapma \\
\hline İş Doyumu & 250 & 14 & 70 & 49 & 13,07 \\
\hline
\end{tabular}

İş Doyumu Ölçeği'nden alınan puanlara bakıldığında, alınan minimum puanın 14, maksimum puanın 70; ölçek ortalamasının ise 49 olduğu ve bu puanın ölçek orta puanının (42) üzerinde olduğu görülmektedir. Ayrıca öğretmenlerin İş Doyumu Ölçeği'nin puanının (Medyan=49) iş doyumları 
yüksektir sınırı olan 49-59 puan aralığında yer alması, araştırmaya katılan öğretmenlerin iş doyumlarının yüksek olduğu şeklinde yorumlanabilir.

\section{Öğretmenlerin İş Doyumlarının Cinsiyet Değişkenine Yönelik Bulgular}

Öğretmenlerin iş doyumlarının cinsiyet değişkenine göre manidar şekilde farklılık gösterip göstermediğini incelemek için Mann Whitney U testi yapılmış, bulgular Tablo 11'de sunulmuştur.

Tablo 11. Öğretmenlerin iş doyumu test puanlarının cinsiyete göre sonuçlarn

\begin{tabular}{llllllll}
\hline Değişkenler & Cinsiyet & $\mathbf{n}$ & S.O & S.T & U & z & p \\
\hline \multirow{2}{*}{ İş Doyumu } & Kadın & 129 & 127,69 & 16472,50 & \multirow{2}{*}{7521,500} & \multirow{2}{*}{-496} & \multirow{2}{*}{620} \\
\cline { 2 - 5 } & Erkek & 121 & 123,16 & 14902,50 & & \\
\hline
\end{tabular}

${ }^{*} \mathrm{p}<0,05$

Tablo 11 incelendiğinde İş Doyumu Ölçeği'ni 121 Erkek, 129 Kadın öğretmenin cevapladığı, erkek öğretmenlerin ölçekten aldıkları toplam puanların sıra ortalamasının 123,16, kadın öğretmenlerin ise 127,69 olduğu görülmektedir. Öğretmenlerin iş doyumu ölçeğinden aldıkları puanlarda kadın öğretmenler lehine anlamlı farklılık $(\mathrm{p}<.05)$ olduğu görülmüsstür.

\section{Öğretmenlerin İş Doyumlarnnı Branş Değişkenine Yönelik Bulgular}

İş Doyum Ölçeği puanlarının öğretmenlerin branşlarına göre farklılaşıp farklılaşmama durumunu ortaya koymak amaciyla Kruskal Wallis testi yapılmıs, bulgular Tablo 12'de verilmiştir.

Tablo 12. Branşa göre iş doyumu ölçeği puanlarna ilişkin sonuçlar

\begin{tabular}{|c|c|c|c|c|c|}
\hline Değişkenler & Branş & $\mathbf{n}$ & $\begin{array}{l}\text { Gruplar Arası } \\
\text { Fark }\end{array}$ & $\begin{array}{l}\text { Kruskal } \\
\text { Wallis }\end{array}$ & $\mathbf{p}$ \\
\hline \multirow[t]{8}{*}{ İş Doyumu } & Sinuf Ögr. & 61 & 143,01 & \multirow[t]{8}{*}{18,489} & \multirow[t]{8}{*}{,010 } \\
\hline & Türkçe Ögr. & 23 & 124,59 & & \\
\hline & Matematik Ögr. & 36 & 85,90 & & \\
\hline & Sosyal Bilgiler Ögr. & 11 & 155,50 & & \\
\hline & Fen Bilimleri Ögr. & 29 & 120,67 & & \\
\hline & Diğer Branş Ögr. & 47 & 121,12 & & \\
\hline & Yabancı Dil Ögr. & 31 & 127,13 & & \\
\hline & Yetenek Zümresi Öğr. & 12 & 154,17 & & \\
\hline
\end{tabular}

${ }^{*} \mathrm{p}<0,05$ 
Tablo 12'de, Öğretmenlerin branşlarına göre İş Doyum Ölçeği'nden puanlarının anlamlı $(\mathrm{p}<, 05)$ farklılıklar gösterdiği görülmüştür. Farklılığın hangi gruptan kaynaklandığını belirlemek için nonparametrik testlerde parametrik testlerdeki gibi özel karşılaştırma testleri bulunmamaktadır. Bu yüzden de Mann Whitney U testi uygulanarak ikili karşılaştırmalar yapılmış, Sonuçlar Tablo 13'de verilmiştir.

Tablo 13. Öğretmenlerin branşlarnna göre mann whitney $u$ testi sonuçlar

\begin{tabular}{|c|c|c|c|c|c|c|}
\hline Değişkenler & Okul Türü & n & Sira Ort. & $\mathbf{z}$ & $\mathrm{U}$ & $\mathbf{p}$ \\
\hline \multirow{8}{*}{ İş Doyumu } & Sinıf Ögr. & 61 & 57,61 & \multirow[t]{2}{*}{$-3,927$} & \multirow[t]{2}{*}{572,500} & \multirow[t]{2}{*}{,000 } \\
\hline & Matematik Ögr. & 36 & 34,40 & & & \\
\hline & Matematik Ögr. & 36 & 21,26 & \multirow[t]{2}{*}{$-2,479$} & \multirow[t]{2}{*}{99,500} & \multirow[t]{2}{*}{,013 } \\
\hline & Sosyal Bilgiler Ögr. & 11 & 32,95 & & & \\
\hline & Matematik Ögr. & 36 & 28,99 & \multirow[t]{2}{*}{$-2,272$} & \multirow[t]{2}{*}{377,500} & \multirow[t]{2}{*}{,023 } \\
\hline & Yabancı Dil Ögr. & 31 & 39,82 & & & \\
\hline & Matematik Ögr. & 36 & 21,60 & \multirow[t]{2}{*}{$-2,491$} & \multirow[t]{2}{*}{111,500} & \multirow[t]{2}{*}{,013 } \\
\hline & Yetenek Zumresı Ö & 12 & 33,21 & & & \\
\hline
\end{tabular}

${ }^{*} \mathrm{p}<0,05$

Tablo 13'e göre İş Doyumu Ölçeği'ni dolduran Matematik branş öğretmenlerinin iş doyumları Sınıf, Sosyal Bilgiler, Yabancı Dil ve Yetenek zümresi öğretmenlerinkinden anlamlı bir şekilde düşük olduğu görülmüştür.

\section{Öğretmenlerin İş Doyumlarının Deneyim Değişkenine Yönelik Bulgular}

Öğretmenlerin deneyimlerine göre İş Doyumu Ölçeği puanlarının farklılaşıp farklılaşmama durumunu ortaya koymak amaciyla Kruskal Wallis testi yapılmış, bulgular Tablo 14'de verilmiştir.

Tablo 14. Deneyimlere göre iş doyumu ölçeği puanlarna ilişkin sonuçlar

\begin{tabular}{|c|c|c|c|c|c|}
\hline Değişkenler & Deneyim & $\mathbf{n}$ & Gruplar Arası Fark & Kruskal Wallis & $\mathrm{p}$ \\
\hline \multirow{4}{*}{ İş Doyumu } & $1-5$ yl & 42 & 123,87 & \multirow[t]{4}{*}{3,108} & \multirow[t]{4}{*}{,375 } \\
\hline & 6-10 yil & 60 & 120,21 & & \\
\hline & $11-15 \mathrm{yll}$ & 68 & 117,77 & & \\
\hline & 15 yll ve üzeri & 80 & 136,89 & & \\
\hline
\end{tabular}

${ }^{*} \mathrm{p}<0,05$

Tablo 14 incelendiğince İş Doyumu Ölçeği'nden alınan puanlarda öğretmenlerin deneyimlerine göre anlamlı bir farklılık (p>.05) olmadı̆̆ görülmüştür. 


\section{Öğretmenlerin İş Doyumlarının Mezuniyet Değişkenine Yönelik Bulgular}

Öğretmenlerin İş Doyumu Ölçeği test puanlarının mezun oldukları okul türlerine göre farklılaşıp farklılaşmama durumunu ortaya koymak amaciyla Kruskal Wallis testi analizi yapılmış, bulgular Tablo 15'de verilmiştir.

Tablo 15. Öğretmenlerin mezun olduklarn okullara göre iş doyumu ölçeği puanlarna ilişkin sonuçlar

\begin{tabular}{llllll}
\hline \multirow{2}{*}{ Değişkenler } & Okul Türü & $\mathbf{n}$ & $\begin{array}{l}\text { Gruplar } \\
\text { Arası Fark }\end{array}$ & $\begin{array}{l}\text { Kruskal } \\
\text { Wallis }\end{array}$ & $\mathbf{p}$ \\
\hline \multirow{3}{*}{ İş Doyumu } & Lisans & 205 & 124,14 & \multirow{2}{*}{6,062} &, 048 \\
\cline { 2 - 5 } & Önlisans/Yüksekokul & 12 & 174,21 & & \\
\cline { 2 - 5 } & Yükseklisans/Doktora & 33 & 116,26 & & \\
\hline
\end{tabular}

${ }^{*} \mathrm{p}<0,05$

Tablo 15 incelendiğince öğretmenlerin İş Doyumu Ölçeği'nden aldıkları puanlarını mezun oldukları okul türlerine göre anlamlı $(\mathrm{p}<, 05)$ farklılıklar gösterdiği görülmüştür. Farklılığın hangi gruptan kaynaklandığını belirlemek için nonparametrik testlerde parametrik testlerdeki gibi özel karşlaştırma testleri bulunmamaktadır. Bu yüzden de Mann Whitney U testi uygulanarak ikili karşılaştırmalar yapılmış, sonuçlar Tablo 16'da verilmiştir.

Tablo 16. Öğretmenlerin mezun olduklarn okullara göre mann whitney u testi sonuçlarn

\begin{tabular}{lllllll}
\hline Değişkenler & Okul Türü & $\mathbf{N}$ & Sıra Ort. & $\mathbf{z}$ & $\mathbf{U}$ & $\mathbf{p}$ \\
\hline \multirow{4}{*}{ İş Doyumu } & Lisans & 205 & 106,57 & $-2,362$ & 731,000 & \multirow{2}{*}{018} \\
\cline { 2 - 5 } & Önlisans/Yüksekokul & 12 & 150,58 & & & \\
\cline { 2 - 5 } & Önlisans/Yüksekokul & 12 & 30,13 & $-2,196$ & 112,500 & \multirow{2}{*}{028} \\
\cline { 2 - 5 } & Yükseklisans/Doktora & 33 & 20,41 & & & \\
\hline
\end{tabular}

${ }^{*} \mathrm{p}<0,05$

Tablo 16'ya göre İş Doyumu Ölçeği'ni dolduran Onlisans/Yuksekokul mezunu öğretmenlerinin iş doyumları Lisans ve Yukseklısans/Doktora mezunu öğretmenlerinkinden manidar bir biçimde yüksek olduğu görülmüştür. 
Öğretmenlerin yaşam boyu öğrenme eğilimleri ile iş doyumları arasındaki ilişkiye ilişkin bulgular

Öğretmenlerin yaşam boyu öğrenme eğilimleri ile iş doyumları arasındaki ilişkiyi belirlemek için Spearman Korelasyon katsayısı hesaplanmış, bulgular Tablo 17'de verilmiştir.

Tablo 17. Öğretmenlerin yaşam boyu öğrenme eğilimleri ile iş doyumlarn arasındaki ilişki

\begin{tabular}{lllll}
\hline & & $\mathrm{r}_{\mathrm{s}}$ & $\mathrm{R}^{2}$ & $\mathrm{p}$ \\
\hline \multirow{2}{*}{ Değişkenler } & Yaşam Boyu Öğrenme Eğilimleri & \multirow{2}{*}{0,25} & \multirow{2}{*}{0,0625} & \multirow{2}{*}{$0,000^{*}$} \\
\cline { 2 - 2 } & İş Doyumu & & \\
\hline
\end{tabular}

${ }^{*} \mathrm{p}<0,01$

Öğretmenlerin yaşam boyu öğrenme eğilimleri ile iş doyumları arasındaki korelasyon katsayısının .25 olduğu görülmüştür. Yani Öğretmenlerin yaşam boyu öğrenme eğilimleri ile iş doyumları arasında düşük düzeyde anlamlı $(p=0,000)$ bir ilişki olduğu görülmüştür. Determinasyon katsayısına baktığımızda Yaşam boyu öğrenme ölçeğinden alınan puanın \% 6'sı İş doyumu ölçeğinden alınan puandan ileri geldiği görülmektedir.

\section{Sonuç, Tartışma Ve Öneriler}

$\mathrm{Bu}$ araştırma ile öğretmenlerin yaşam boyu öğrenme eğilimleri ile iş doyumları arasındaki ilişkiyi incelemek için ilkokul ve ortaokulda farklı branşlarda görev yapan toplam 250 öğretmen ile çalışılmıştır.

Araştırmanın birinci sorusu, öğretmenlerin yaşam boyu öğrenme eğilimlerinin düzeyini belirlemektir. Yapılan analizler sonucunda öğretmenlerin yaşam boyu öğrenme eğilimlerinin yeterli olduğu sonucuna ulaşılmıştır. Alan yazın tarandığında araştırma sonuçları ile paralellik gösteren çalışmalara (Şahin vd.,2010; Gencel, 2013; Karakuş, 2013; Yavuz Konakman ve Yanpar Yelken, 2014; Şahin ve Arcagök, 2014; Yıldırım, 2015; Kazu ve Erten, 2016; Özgür, 2016; Adabaş, 2016; Pınarcık vd., 2016; Pilli, Sönmezler ve Göktan, 2017; Abbak, 2018) rastlanırken Diker Coşkun (2009) ve Tunca, Alkın Şahin ve Aydın (2015) öğretmen adayları ile yaptıkları çalışmalarında araştırma sonuçlarının aksine öğretmenlerin eğilimlerinin düşük olduğu sonucuna ulaşmıştır. Özçiftçi ve Çakır (2015), sürekli gelişen bilgi çağında, ken- 
dini geliştirmeyen, öğrenim-öğretim sürecine ve tecrübelerine yeni bilgi ve becerileri eklemeyen öğretmenlerin gelişim gösteremeyeceklerini ve sürekliliklerini sürdüremeyeceklerini belirtmiştir. Yaşam boyu öğrenme becerisine sahip olan ve bu becerileri etkili şekilde kullanarak öğrencilerine rol model olan öğretmenler, bu becerileri kolaylıkla öğrencilerinin kazanmasını da sağlayacaktır. Bu sayede de küreselleşen dünyada çağın gelişmelerini hızla takip eden ve uyum sağlayan nesiller yetiştirecek, yaşam boyu öğrenen bir toplumun oluşmasına büyük katkı sağlamış olacaklardır. Ayrıca öğretmenlerin yaşam boyu öğrenme eğilimlerinin cinsiyetlerine, branşlarına, deneyimlerine, mezuniyetlerine göre anlamlı olarak farklılaşıp farklılaşmadığı incelenmiştir. Öğretmenlerin Yaşam Boyu Öğrenme Eğilimleri Ölçeğinden ve Öğrenmeyi Düzenlemede Yoksunluk alt ölçeğinden aldıkları puanlarda cinsiyete göre kadın öğretmenler lehine anlamlı farklılık olduğu görülmüştür. Alanyazında bu bulguyu destekleyen çalışmalar (Demirel ve Akkoyunlu, 2010; Diker Coşkun, 2009; Şahin, Akbaşlı ve Yanpar Yelken, 2010) olduğu görülmüştür. Jenkins (2004), yaşam boyu öğrenme kavramına, kadın okuryazar oranının (temel eğitim) erkeklere oranla daha az olmasından dolayı kadınların daha çok ihtiyaç duyduğunu ve kadınların bu eksikliklerini kapatmak için daha çok uğraştıklarını ve kendilerini her ortam ve fırsatta geliştirmeye çalıştıkların belirtmiştir. Ayrıca kadınların ailede üstlendikleri sorumlulukları sebebiyle işten ayrılma, farklı bir işe başlama veya bir süre çalışmama kararı alma vb. durumlarla fazlasıyla karşılaştıklarını, bu durumlarla başa çıkmak adına değişime hemen adapte olmak için daha çok uğraştıklarını, bu durumun da yaşam boyu öğrenme yeterliklerini arttırd1ğını belirtmektedir. Öğretmenlerin branşlarına ve deneyimlerine göre Yaşam Boyu Öğrenme Eğilimleri Ölçeğinde ve alt testlerinde anlamlı farklılıklar olmadığ1 görülmüştür. Yaşam Boyu Öğrenme ölçeği, Motivasyon ve Sebat alt testinde Lisans mezunu öğretmenlerin aldıkları puan ortalamalarının Önlisans/Yüksekokul mezunu öğretmenlerden manidar bir şekilde düşük olduğu görülmüştür. Ayrıca Motivasyon ve Sebat alt testlerinden Lisans mezunu öğretmenlerin aldıkları puan ortalamalarının Yükseklisans/Doktora mezunu öğretmenlerden manidar bir şekilde düşük olduğu görülmüştür.

Araştırmanın ikinci sorusu öğretmenlerin iş doyumlarının düzeyini belirlemektir. Yapılan analizler sonucunda öğretmenlerin iş doyumlarının yüksek olduğu görülmüştür. Alan yazın taramasında araştırma sonuçları ile 
paralellik gösteren çalışmaların (Günbayı, 2001; İdi, 2017; McNally, Gray ve Blake, 2006; Omondi, 2012; Polatkan, 2016) olduğu görülmüştür. Ancak öğretmenlerin iş doyumlarının kısmen olduğu ya da düşük olduğu çalışmalara da (Şahin, 1999; Crossman ve Haris, 2006; Demir, 2001; Demirel, 2006; Kale, 2007; Mora, Ada ve Carbonell, 2009; Omondi, 2012) rastlanmıştır, Eğitimin niteliği ve kalitesi öğretmenlerin yaptıklanı işten doyum sağlayıp sağlamamalarına bağlı olarak değişmektedir (Gamsız, Yazıcı ve Altun, 2013; Tunacan ve Çetin, 2009). Kişilik özellikleri, mesleki başarı, beceri ve yeteneklerin düzeyi, takdir görme, moral, motivasyon, çalışma ortamı, iş yoğunluğu ve buna dayalı olarak ortaya çıkan iş sorumluluğu, ödül yönetimi, okulun sahip olduğu fiziki imkanlar vb faktörler öğretmenlerin iş doyumları üzerinde etkili olmaktadır. (Günbayı ve Tokel, 2012; Şahin ve Dursun, 2009; Şen, 2011). Araştırmalarda çıkan bu farklılığın yukarıdaki faktörlerden kaynaklanabileceği düşünülmektedir. Öğretmenlerin iş doyumu ölçeğinden aldıkları puanlarda cinsiyete göre kadın öğretmenler lehine anlamlı farklılık olduğu görülmüştür. Alanyazında bu bulguyu desteklemeyen çalışmalar (Telef, 2011; Gençtürk ve Memiş, 2010; Gençay, 2007; Papin, 2005; Gülay, 2006) olduğu görülmüştür. Matematik branş öğretmenlerinin iş doyumları Sınıf, Sosyal Bilgiler, Yabanc Dil ve Yetenek zümresi öğretmenlerinkinden anlamlı bir şekilde düşük olduğu sonucuna ulaşılmıştır. Literatürde Gençtürk ve Memiş (2010)'in sinıf ve branş öğretmenleriyle yürüttüğü araştırmada; öğretmenlerin iş doyumlarının anlamlı bir şekilde birbirinden farklı olduğu görülmüştür. Öğretmenlerin deneyimlerine göre iş doyumlarında anlamlı bir farklılık olmadığı görülmüştür. Araştırma sonuçları ile aynı sonuçlara sahip çalışmalar (Telef, 2011; Şahin ve Dursun, 2009; Gençay, 2007; Avşaroğlu ve diğerleri, 2007) varken, araştırma sonucundan farklı sonuçlara ulaşılan çalışmaların da olduğu (Gençtürk ve Memiş, 2010; Günbayı ve Toprak, 2010; Şahin, 1999) görülmüştür. İş doyumu ölçeğini dolduran Önlisans/Yüksekokul mezunu öğretmenlerinin iş doyumları Lisans ve Yükseklisans/Doktora mezunu öğretmenlerinkinden anlamlı bir şekilde yüksek olduğu görülmüştür.

$\mathrm{Bu}$ araştırmanın amacı öğretmenlerin yaşam boyu öğrenme eğilimleri ile iş doyumları arasındaki ilişkilerin belirlenmesidir. Yapılan çalışmada öğretmenlerin yaşam boyu öğrenme eğilimleri ve iş doyumları arasında düşük düzeyde anlamlı bir ilişki bulunmuştur. Araştırma sonucundan farklı olarak çağın gereksinimlerine uyum sağlayabilen, kendisini geliştiren ve yenileyen 
öğretmenlerin iş doyumlarının diğer öğretmenlere nazaran daha yüksek olması beklenmektedir.

Yapılan çalışma iş doyumları ile yaşam boyu öğrenme eğilimleri arasındaki ilişkidir. Bundan sonraki yapılacak çalışmaların öğretmenlerin iş doyumlarını etkileyen veya etkilediği düşünülen farklı değişkenlerle (mesleki tutum, yaşam doyumu, devlet-özel okul faktörü, kişilik özelliği vb) çalışılmasının kuramsal temele katkı getireceği düşünülmektedir. 


\title{
EXTENDED ABSTRACT
}

\section{Investigating the Relationship Between Lifelong Learning Trends and Job Satisfaction of Teachers}

\author{
Şeyda Sevinç - Mustafa Çelebi \\ Erciyes University
}

Lifelong learning can be defined as a basic concept that encompasses all activities carried out in and out of school so edit people's awareness and skills announced to life regardless of their level of education, age, economic status and so on. The terms of lifelong learning was announced in the 1920s by Eduard Lindeman, Basil Yeaxle and John Dewey, one of the thinkers who shed light on constructivist theory. Lifelong learning has entered the world's agenda in the last quarter of the 21st century and has entered Turkey's agenda in the 2000s. In the Turkish education system, this approach has been given great importance and a unit named "Lifelong Learning" is established under the Ministry of National Education. In the information age that we live in, an individual needs to know how to use, interpret, change and create new information. Since information is renewed very quickly in the information age, individuals should know how to learn to learn. Undoubtedly, the biggest task here belongs to schools, teachers who will be role models for individuals. According to lifelong learning approach the trainer; should be a guide for students or learners to set their own goals and determine the paths to be taken to achieve this goal. The desired quality in educational institutions is realized with individuals. The willingness of teachers or employees is of immense significance for the quality of provided education. Job satisfaction is one of the efficient variant that assist to the advance of the quality of work and the significant of the work done by teachers. Job plesure can be related as the level of satisfaction that an individual reaches because of evaluating his / her job or the process related to his / her job. Environmental (work and environment), psychological (personality, behavior, attitude) and demographic (age, gender) characteristics 
have many effects on individuals' job satisfaction. When the academic works is checked out, it is seen that the variables affecting the job satisfaction and lifelong learning tendencies of teachers are frequently examined. But, little academic works have checked out the accord between the two. In this working, the relationship between teachers' lifelong learning tendencies and job satisfaction is tried to be checked out. It is thought that examining teachers' lifelong learning tendencies and job satisfaction together will give researchers and researchers a different perspective. This research, which examines the relationship between teachers' lifelong learning tendency and job satisfaction, is a descriptive survey model therefore it purpose to describe the current condition as it is. It is also a correlational survey model therefore it purpose to complete the degree of the relationship between two or more variables. The research was conducted with a total of 250 teachers working in Kayseri. While establishing the study group of the research, convenience sampling was selected among the purposeful sampling types. Just as the branches in the sample distribution, it was observed that the most of the teachers were classroom teachers and the least of the social studies and talent group teachers participated in the research. In terms of gender, the number of female and male teachers is close to each other and the majority of the teachers have undergraduate degrees. In addition, the majority of the teachers who participated in the research had experience of 15 years or more. In the research, "Personal Information Form", "Lifelong Learning Tendency Scale" and "Job Satisfaction Scale" were applied. In the personal information form, the participants were asked about the independent variables of the study. The application was accomplish by the researchers in the 2018-2019. After the data was edited, it was made suitable for analysis in SPSS program. Without responding sub-problems, distribution characteristics were determined and descriptive statistics were calculated. At the end of the analyzed statistics, it was found that the data related to the scales were not normally distributed ( $\mathrm{p}<.05)$. In the analysis of the data, "Mann Whitney U", "Kruskal Wallis "and "Spearman's Correlation Coefficient" were used. The answers given in the Lifelong Learning Tendency Scale ranged from 1 to 6 points. The rating items consist of the options "6: Very fits" and "1: Not at all". The answers given in the Job Satisfaction Scale ranged from 1 to 5 points. Grading items are answered as "1-Never satisfies $m^{\prime \prime}$ and "5-satisfies me very much". The first question of the research is to 
determine the level of lifelong learning tendencies of teachers. At the end of the analyzes, teachers had lifelong learning tendencies. Addedly, it has been checked out whether the lifelong learning tendencies of teachers differ significantly according to their gender, branches, experiences and graduation. It was seen that there was a important anormaly in favor of female teachers in terms of the scores obtained from the Lifelong Learning Trends Scale and the Deprivation of Learning Arrangement subscale. The second question of the research is to check out the level of job satisfaction of teachers. As a result of the analyzes, it was seen that the teachers' job satisfaction was high. It was seen that there was a important anormaly in the scores of teachers from job satisfaction scale in favor of female teachers due to gender, and job satisfaction of mathematics branch teachers was significantly lower than Class teachers, Social Studies, Foreign Language and Talent teachers. In addition, there was no important anormaly in job satisfaction according to the teachers' experiences, but it was found that the job satisfaction of the teachers who has associate degree diploma was significantly higher than the teachers who has postgraduate and doctorate diploma. The porpose of this study is to check out the relationship between teachers' lifelong learning tendencies and job satisfaction. In the study, a significant low level relationship was found between teachers' lifelong learning tendencies and job satisfaction. Unlike the results of the research, it is expected that the job satisfaction of teachers who can adapt to the needs of the age, develop and renew themselves is higher than other teachers. The study is the relationship between job satisfaction and lifelong learning tendencies. It is thought that working with different variables (professional attitude, life satisfaction, state-private school factor, personality traits, etc.) that affect or affect teachers' job satisfaction will contribute to the theoretical foundation. It is thought that working with different variables (professional attitude, life satisfaction, state-private school factor, personality traits, etc.) that affect or thought to affect teachers' job satisfaction will contribute to the theoretical foundation.

\section{Kaynakça / References}

Abbak, Y. (2018). Öğretmenlerin yaşam boyu öğrenme yeterlikleri ile yenilikçilik düzeylerinin incelenmesi. Yayımlanmamış Yükseklisans tezi, Erciyes Üniversitesi Eğitim Bilimleri Enstitüsü. 
Adabaş, A. (2016). Bartın Üniversitesi lisansüstü eğitim öğrencilerinin yaşam boyu öğrenmede anahtar yeterliklere sahip olma düzeyleri. Yayımlanmamış Yüksek Lisans Tezi. Bartın Üniversitesi Eğitim Bilimleri Enstitüsü, Bartın.

Akkoyunlu, B. ve Kurbanoğlu, S. (2002). Öğretmenlere bilgi okuryazarlığı becerilerinin kazandırılması üzerine bir çalışma. Türk Kütüphaneciliği, 16, 123-138.

Akkuş, N. (2008). Yaşam boyu öğrenme becerilerinin göstergesi olarak 2006 pısa sonuçlarnnın Türkiye açısından değerlendirilmesi. Yayımlanmamış Yüksek Lisans Tezi. Hacettepe Üniversitesi Sosyal Bilimler Enstitüsü. Ankara.

Alıç, M. (1996). Eğitim sisteminin amaçlarının gerçekleştirilmesinde eğitim yöneticisinin işlevleri. Çă̆daş Eğitim Dergisi, 217, 12-16.

Atik Kara, D. ve Kürüm D. (2007). Sınıf öğretmeni adaylarının yaşam boyu öğrenme kavramına yükledikleri anlam (Anadolu Üniversitesi Eğitim Fakültesi Örneği) 16. Ulusal Eğitim Bilimleri Kongresi'nde sunulan bildiri (5-7 Eylül 2007). Gaziosmanpaşa Üniversitesi, Tokat.

Avrupa Komisyonu (2002). European report on quality indicators of life long learning. fifteen quality indicators. European commission report, directorate- general for educationand culture, Brussels. 20. 04. 2019 tarihinde http://www.aic.lv/ace/ace disk/Bologna/contrib/EU/report qual\%20LLL.pdf erişilmiştir.

Avşaroğlu, S., Deniz, M. E. ve Kahraman, A., (2005). Teknik öğretmenlerde yaşam doyumu iş doyumu ve mesleki tükenmişlik düzeylerinin incelenmesi. Selçuk Üniversitesi Sosyal Bilimler Enstitüsü Dergisi, 14, 115-129.

Ayra, M. ve Kösterelioğlu, İ. (2015). Öğretmenlerin yaşam boyu öğrenme eğilimlerinin mesleki öz yeterlik algıları ile ilişkisi. Education Sciences, 9(5), 17-28.

Büyüköztürk, Ş. (2004). Sosyal bilimler için veri analizi el kitabı. Ankara: Pegem A Yayincilik.

Çelik, H. (2003). Fen Bilgisi, Fizik, Kimya, Biyoloji öğretmenlerinin iş Doyumu: Kırıkkale İl örneği. Yayınlanmamış yüksek lisans tezi, Kırıkkale Üniversitesi, Kırıkkale.

Demato, D ve Curcio, C. (2004). Job satisfaction of elemantary school counselors. Professional School Counseling, 7, 236-246.

Demir, E. (2001). Sinf öğretmenlerinin iş doyumunu etkileyen olası faktörler ve bu faktörler kapsamında sını öğretmenlerinin iş doyumlarının ölçülmesi. Yayımlanmamış yüksek lisans tezi, Gazi Üniversitesi Eğitim Bilimleri Enstitüsü, Ankara.

Demirel, F. (2006). Sınıf öğretmenlerinin iş doyum düzeyleri. Yayımlanmamış yüksek lisans tezi, Pamukkale Üniversitesi Sosyal Bilimler Enstitüsü, Denizli. 
Demirel, M. ve Akkoyunlu, B. (2010). Öğretmen adaylarınn yaşam boyu öğrenme eğilimleri ve bilgi okuryazarlığı özyeterlilik algıları. 10 th. International Educational Technology Conference, Boğaziçi Üniversitesi, İstanbul, Proceedings Book, 2, 1126- 1133.

Diker Coşkun, Y. D. (2009). Üniversite öğrencilerinin yaşam boyu öğrenme eğilimlerinin bazı değgişkenler açısından incelenmesi. Yayınlanmamış Doktora Tezi, Hacettepe Üniversitesi, Ankara.

Dilsiz, B. (2006). Konya İlindeki ortaöğretim okullarnda çalışan öğretmenlerin tükenmişlik ve iş doyumu düzeylerinin bölgelere göre değerlendirilmesinin çok değişkenlik istatistiksel analizi. Yayınlanmamış yüksek lisans tezi, Selçuk Üniversitesi, Konya.

Dinevski, D. ve Dinevski, I. V. (2004). The concepts of university lifelong learning provision in Europe. Transition Studies Review, 11 (3), 227-235.

Dinham, S. ve Scott, C. (1996). Teacher satisfaction, motivation and health. ERIC Documents, ED 405295.

Ekiz, D. (2006), Self-observation and peer observation : Reflective diaries of primary student- teachers, Elementary Education Online.5(1), 47-57.

Erdem, A.R. ve Demirel, F. (2009). Sınıf Öğretmenlerinin "denetim" boyutuna ilişkin iş doyum düzeyi. E-Journal of New World Sciences Academy (4)1.

Evin Gencel, İ. (2013). Öğretmen adaylarının yaşam boyu öğrenme yeterliklerine yönelik algiları. Educationand Science, 38(170), 237-252.

Gamsız, Ş., Yazıcı, H. ve Altun, F. (2013). Öğretmenlerde a tipi kişilik, stres kaynakları, öz yeterlik ve iş doyumu. TurkishStudies. 8(8), 1475-1488.

Gedik, T., Akyüz, K.C.,ve Batu, C. (2009). Orman endüstri işletmelerinde yönetici iş tatmin düzeyinin belirlenmesi:Düzce ili örneği. Kastamonu Üniversitesi, Orman Fakültesi Dergisi, 9 (1), 1-11.

Gençay, Ö. A. (2007). Beden Eğitimi öğretmenlerinin iş doyumu ve mesleki tükenmişliklerinin bazı değişkenler açısından incelenmesi. Kastamonu Eğitim Dergisi, 15(2), 765-780.

Gençtürk, A. ve Memiş, A. (2010). İköğretim okulu öğretmenlerinin öz-yeterlik algıları ve iş doyumlarının demografik faktörler açısından incelenmesi. ilköğretim Online, 9(3), 1037-1054

Gencel, İ.E. (2013). Öğretmen adaylarının yaşam boyu öğrenme yeterliklerine yönelik algiları. Educationand Science, 38(170), 237-252.

Girgin, G. (2009). Öğretmenlerin iş doyumuna etki eden faktörlerin incelenmesi. NEWWSA, 4(4), 1297- 1307 
Goodrich, A.T. (2015). An investigation of the perceived development of the life-long learning skills of division 1 student-athletes. Ph.D. dissertation, University of South Florida.

Güçlü, M. (2019). Yaşamboyu öğrenmenin önemi ve temel özellikleri. Yetişkin Eğitimi ve Hayatboyu Öğrenme, Ankara: Pegem Yayıncllı.

Gülay, H.E. (2006). Beden Ĕ̈itimi öğretmenlerinin iş doyum düzeylerinin arasttırlmast: Kocaeli İli örneği. Yayınlanmamış yüksek lisans tezi, Sakarya Üniversitesi, Sakarya.

Güleç, İ., Çelik, S. ve Demirhan, B. (2013). Yaşam boyu öğrenme nedir? kavram ve kapsamı üzerine bir değerlendirme. Sakarya University Journal of Education, 2(3), 34-48. Retrieved from http://dergipark.org.tr/suje/issue/20631/219952.

Günbayı, İ. (2001). Illköğretim okulu öğretmenlerinin iş doyumu. Kuram ve Uygulamada Ĕ̈itim Bilimleri, 1(2), 93-112.

Günbayı, İ. ve Tokel, A. (2012). İlköğretim okulu öğretmenlerinin iş doyumu ve iş stresi düzeylerinin karşlaştırmalı analizi. Ordu Üniversitesi Sosyal Bilimler Enstitüsü Dergisi. 3(5), 77-95.

Günbayı, İ. ve Toprak, D. (2010). İlköğretim okulu sınıf ve özel sınıf öğretmenlerinin iş doyum düzeylerinin karşılaştırılması. Illköğretim Online, 9(1), 150-169.

Gürbüz, Z. (2008). Kars Ilinde görevli okul öncesi öğretmenlerinin iş tatmin düzeyleri ve mesleki tükenmişlik düzeylerinin incelenmesi. Yayınlanmamış yüksek lisans tezi, Marmara Üniversitesi, İstanbul.

Hops, J., ve Reschly, D. (2002). Regional differences in school psychology practice. School Psychology Rewiew, 31,11-30.

Hunde A.B. ve Tacconi G. (2014). Teacher educators' practices from the view of building lifelong learning capabilities in student teachers. Procedıa - Social and behavioral sciences, 136, 496-500. doi:10.1016/j.sbspro.2014.05.363.

İdi, A. (2017) İlkokul ve ortaokullarda örgütsel iklim ile öğretmenlerin iş doyumu arasmdaki ilişki. Yayımlanmamış yüksek lisans tezi, Dokuz Eylül Üniversitesi Eğitim Bilimleri Enstitüsü, İzmir.

Jarman, R., Mcaleese, L. ve Mcconnell, B. (1997). Science and lifelong learning: A survey of science teachers' provision for the promotion of pupils' independent study at Key Stage 4'. Evaluation \& Research in Education, 11(3), 149-163.

Jenkins, A. (2004). Women lifelong learning and employment. Centre for economics of education. U.K. London School of Economics and Political Science.

Kağan, M. (2005). Devlet ve özel ilköğretim okulları ile rehberlik ve araştırma merkezlerinde çalı̧̧an rehber öğretmenlerin iş doyumlarmin incelenmesi. Yayınlanmamış yüksek lisans tezi, Ankara Üniversitesi, Ankara 
Kağan, M. ve Yılmaz, N. (2018). Pedagojik Yenilenme Ve Eğitimde Yeni Yaklaşımlar Programinn Sinf Öğgretmenlerinin İş Doyumu Ve Yaşam boyu Öğrenmeleri Üzerindeki Etkileri, http://earsiv.erzincan.edu.tr/xmlui/bitstream/handle 20.500.12432/3132/sinuf\%20 öğretmen is\%20doyum nyilmaz mkagan.pdf?sequence=1\&isAllowed=y adresinden 21.07.2019 tarihinde alınmıştır.

Kale, F. (2007). Beden Eğitimi öğretmenlerinin iş doyumu ve tükenmişlik düzeylerinin çeşitli değişkenler açısından incelenmesi. Yayımlanmamış yükseklisans tezi, Niğde Üniversitesi Sosyal Bilimler Enstitüsü, Niğde.

Karakuş, C. (2013). Meslek Yüksekokulu öğrencilerinin yaşam boyu öğrenme yeterlikleri. Ë̆itim ve Öğretim Araştrrmaları Dergisi, 2 (3), 26-35.

Karasar, N. (2013). Bilimsel araştırma yöntemi. Ankara: Nobel Yayın Dağıtım.

Kazu, İ. Y. ve Erten, P. (2016). Öğretmenlerin yaşam boyu öğrenme yeterlikleri. Elementary Education Online, 15(3), 838-854.

Kış, A. Gürgür, H. ve Akçamete, G. (2012). Engelli öğretmenlerin iş doyumları ve çalışma koşulları. Mehmet Akif Ersoy Üniversitesi Eğitim Fakültesi Dergisi, 23, $272-294$.

Kirby J. R., Knapper C., Lamon, P. ve Egnatoff W. J. (2010). Development of a scale to measure lifelong learning. International Journal of Lifelong Education, 29(3), 291-302.

Koç, S. Ve İzci, E. (2012). Öğretmen adaylarını yaşam boyu öğrenmeye ilişkin görüşlerinin değerlendirilmesi, Sosyal Bilimler Dergisi, 5 (9), 101-114.

Köymen, Ü. (2015). Yaşam boyu öğrenme ve öğretim, Ankara: Palme Yayınları.

Locke, E.A. (1976). The nature and causes of job satisfaction, in dunnette, M.D. (Ed.), Handbook of Industrial and Organizational Psychology, Rand McNally, Chicago, IL, pp. 1297-1349.

Mc Nally, G. Ve Blake, A. (2006). Job satisfaction among newly qualified teachers in Scotland Institute of Education. University of Stirling, Scotland.

Marx, E., ve Granger, R.C. (1992). The Policy İmplications Of Job Satisfaction Ratings For Recruiting And Retaining Early Childhood Teachers. Child and Youth Care Forum, 21(4), 229-246.

Menon Eliophotou M. ve Reppa, A. A. (2011). Job Satisfaction Among Secondary School Teachers: The Role Of Gender And Experience. School Leadership and Management, 31(5), 435-450. 
Mete. C. (2006). İlköğretim okullarında çalışan öğretmenlerin kişilik özellikleri ile iş tatmin düzeyleri arasındaki ilişkinin incelenmesi. Yayınlanmamış yüksek lisans tezi, Yeditepe Üniversitesi, İstanbul

Mora, T. Ferrer, Ada. Ve Carbonell, I. (2009). The job satisfaction gender gap among young recent university graduates: Evidence from Catalonia. The Journal of Socio-Economics, 38, 581-589.

Omondi, A. A. (2012). Factors influencing job satisfaction of public secondary school teachers In Mombasa County, University Of Nairobi.

Özçifçi, M. ve Çakır, R. (2015) Öğretmenlerin yaşam boyu öğrenme eğilimleri ve eğitim teknolojisi standartları öz yeterliklerinin incelenmesi. Eğitim Teknolojisi Kuram ve Uygulama, 5(1).

Özgür, H. (2016). Öğretmen adaylarının yaşam boyu öğrenme yeterlikleri ve bilgi okuryazarlığı öz-yeterlikleri üzerine bir çalışma. Mersin Üniversitesi Ĕ̆itim Fakültesi Dergisi, 12(1), 22-38.

Öztürk, A., \& Deniz, M.E. (2008). Okul öncesi öğretmenlerin duygusal zeka yetenekleri, iş doyumları ve tükenmişlik düzeylerinin bazı değişkenler açısından incelenmesi. Illkogretim- Online, 7(3), 578-599.

Özyürek, A. (2009). Okul öncesi eğitimi öğretmen ve yöneticilerinin iş doyumu, kişisel özellik ve mesleki algılarının değerlendirilmesi. Milli Ĕ̆gitim Dergisi, 182, 8-21.

Papin, L. M. (2005). Teacher retention and satisfaction among inner-city educators. Unpublished Doctoral Dissertation, Arizona State University.

Pınarcık, Ö. Özözen Danacı, M., Deniz, M. E. ve Eran, N. (2016). Okul öncesi öğretmenlerinin yaşam boyu öğrenme yeterliklerine yönelik algıları. Abant İzet Baysal Üniversitesi Ĕ̆itim Fakültesi Dergisi, 16(4), 1966-1983.

Pilli, O., Sönmezler, A. ve Göktan, N. (2017). Pre-service teachers' tendencies and perceptions towards lifelong learning. European Journal of Social Sciences Education and Research, 10(23), 26-33.

Polatkan, N.N. (2016). Ortaokul öğretmenlerinin duygusal emek davranışları ile iş doyumları arasındaki ilişki. Yüksek Lisans Tezi. Adnan Menderes Üniversitesi Sosyal Bilimler Enstitüsü, Aydın.

Silah, M. (2002). Sanayi işletmelerinde önemli ve çağdaş bir gereksinim: Süreç danışmanlığı uygulamaları. Çukurova Üniversitesi Sosyal Bilimler Dergisi, 26(1), 143-168.

Steward, A. (2009). Continuing your professional development in lifelong learning. London, GBR: Continuum International Publishing. 
Sulu, H. (2007). Resmi ve özel ilköğretim okullarmda çalışan öğretmenlerin iş tatmin düzeyleri ile denetim odağı arasındaki ilişkinin incelenmesi. Yayınlanmamış yüksek lisans tezi, İstanbul Üniversitesi, İstanbul.

Şahin, İ. (1999). İlköğretim okullarında görevli öğretmenlerin iş doyum düzeyleri. (Yayımlanmamış yüksek lisans tezi). Dokuz Eylül Üniversitesi, Eğitim Bilimleri Enstitüsü, İzmir.

Şahin, Ç. ve Arcagök, S. (2014). Öğretmenlerin yaşam boyu öğrenme yeterlikleri düzeyinin çeşitli değişkenler açısından incelenmesi. Adryaman Üniversitesi Sosyal Bilimler Enstitüsü Dergisi. 16, 394-417.

Şahin, H. ve Dursun, A. (2009). Okul öncesi öğretmenlerinin iş doyumları: Burdur örneği. Mehmet Akif Ersoy Üniversitesi Ĕ̆itim Fakültesi Dergisi. 9(18), 160-174.

Şahin, M., Akbaşlı ,S. ve Yanpar Yelken T. (2010). Key competences for lifelong learning: the case of prospective teachers. Educational Research And Review, 5 (10), 545-556.

Şen, B. (2011). Okul öncesi öğretmenlerinin mesleki doyumları ve hizmet içi eğitim ihtiyaçlan üzerine bir araştırma. Yüksek Lisans Tezi. Selçuk Üniversitesi Sosyal Bilimler Enstitüsü, Konya.

Taşdan, M. ve Tiryaki, E. (2008). Özel ve devlet ilköğretim okulu öğretmenlerinin iş doyumu düzeylerinin karşılaştırılması. Eğitim ve Bilim Dergisi. 33(147), 5470.

Telef, B.B. (2011). Öğretmenlerin öz-yeterlikleri, iş doyumları, yaşam doyumları ve tükenmişliklerinin incelenmesi, İlköğretim Online, 10(1), 91-108.

Tunacan, S. ve Çetin, C. (2009). Lise öğretmenlerinin iş doyumunu etkileyen faktörlerin tespitine ilişkin bir araştırma. Marmara Üniversitesi Atatürk Ĕ̆itim Fakültesi Ĕ̆itim Bilimleri Dergisi. 29, 155-172.

Tunca, N., Alkın Şahin, S. ve Aydın, Ö. (2015). Öğretmen adaylarının yaşam boyu öğrenme eğilimleri. Mersin Üniversitesi Eğitim Fakültesi Dergisi, 11 (2), 432446.

Vural, B. (2004), Yetkin-ideal-vizyoner öğretmen. İstanbul: Hayat Yayınları.

Yaman, F. ve Yazar, T. (2015). Öğretmenlerin yaşam boyu öğrenme eğilimlerinin incelenmesi:Diyarbakır ili örneği. Kastamonu Eğitim Dergisi, 23(4), 15531566.

Yavuz Konokman, G. ve Yanpar Yelken, T. (2014). Eğitim fakültesi öğretim elemanlarının yaşam boyu öğrenme yeterliklerine ilişkin algıları. Hacettepe Üniversitesi Ĕ̆itim Fakültesi Dergisi. 29(2), 267-281. 
Yıldırım, Z. (2015). Sınıf öğretmenlerinin yaşam boyu öğrenmeye yönelik yeterlik algıları ve görüşleri. Yayınlanmamış yüksek lisans tezi, Çanakkale On sekiz Mart Üniversitesi, Eğitim Bilimleri Enstitüsü, Çanakkale.

Yıldırım, A. ve Şimşek, H. (2008). Sosyal bilimlerde nitel araştırma yöntemleri. Ankara: Seçkin Yayınevi.

Yılmaz, E., ve Izgar, H. (2009). İköğretimde çalışan öğretmenlerin iş doyumlarının okullardaki örgütsel yaratıcılık açısından incelenmesi. İlköğretim Online, 8(3), 943-951

Yılmaz, K. ve Altınkurt, Y. (2013). Örgütsel iklim ölçeğinin Türkçe'ye uyarlanması: Geçerlik ve güvenirlik çalışması. Trakya Üniversitesi Eğitim Fakültesi Dergisi, 3(1), 1-11.

Zembylas, M. ve Papanastasiou, E. C. (2005). Modeling teacher empowerment: The role of job satisfaction. Educational Research and Evaluation, 11(5), 433-459

\section{Kaynakça Bilgisi / Citation Information}

Sevinç, Ş. ve Çelebi, M. (2020). Öğretmenlerin yaşam boyu öğrenme eğilimleri ile iş doyumları arasındaki ilişkinin incelenmesi. OPUS-Uluslararası Toplum Araştırmaları Dergisi, 16(Özel Sayı), 3533-3564. DOI: 10.26466/opus.696882 